\title{
Left ventricular hypertrabeculation: a clinical enigma
}

\author{
Nelli Ivanova, ${ }^{1}$ Hoda Ahmed, ${ }^{2}$ Wael Abuzeid ${ }^{3}$
}

\begin{abstract}
${ }^{1}$ Tihookeanskij gosudarstvenny] medicinskij universitet,

Vladivostok, Russia

${ }^{2}$ University of Ottawa Faculty of Medicine, Ottawa, Ontario, Canada

${ }^{3}$ Sunnybrook Health Sciences Centre, Toronto, Ontario,

Canada
\end{abstract}

\section{Correspondence to}

Dr Wael Abuzeid,

wael.abuzeid@mail.utoronto.ca

Accepted 3 November 2016

\section{DESCRIPTION}

A woman aged 25 years was referred to cardiology for atypical chest pain. This was described as sharp non-exertional left-sided chest pain lasting a few seconds. Vitals showed BP 122/85 and pulse $87 \mathrm{bpm}$. Cardiovascular examination revealed normal S1 and S2, an S4 and no murmurs. ECG showed normal sinus rhythm. Transthoracic echocardiography showed marked trabeculation of the apical lateral segments (figure 1). Cardiac MRI confirmed these trabeculations with no diagnostic criteria for non-compaction.

Left ventricular (LV) hypertrabeculation is defined by the presence of three or more trabeculations apically and up to the level of papillary muscles, seen in one echocardiographic view. ${ }^{1}$ It can be distinguished from left ventricular noncompaction (LVNC) by the absence of thin compacted myocardial layer. Hypertrabeculation is observed more often in competitive athletes, specifically in Afro-American individuals ${ }^{2}$ or in patients with increased preload such as in sickle cell disease. ${ }^{1}$ It can also be seen in patients with LVNC, hypertrophic cardiomyopathy, dilated cardiomyopathy, peripartum cardiomyopathy and neuromuscular disorders with cardiac involvement.

On the other hand, LVNC is a rare congenital cardiomyopathy with a rare prevalence of between

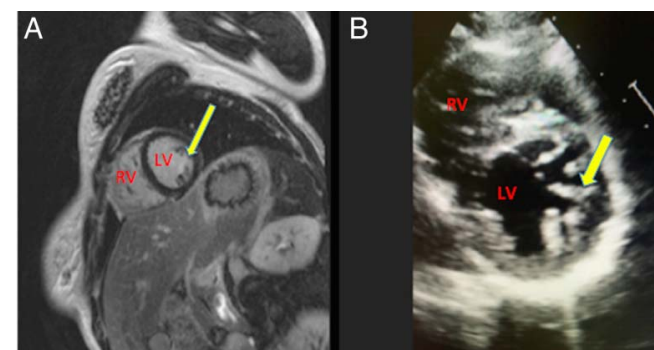

To cite: Ivanova $\mathrm{N}$ Ahmed H, Abuzeid W. BMJ Case Rep Published online: [please include Day Month Year] doi:10.1136/bcr-2016217526
CrossMark

Figure 1 (A) Cardiac MRI showing the short-axis view of the left ventricle (LV) demonstrating hypertrabeculation appearance (yellow arrow). (B) Two-dimensional echo short-axis view of the LV showing prominent trabeculations (yellow arrow). LV, left ventricle; RV, right ventricle.
$0.014 \%$ and $1.3 \%$ in the general population. It is characterised by a thin, compacted myocardial layer and an extensive non-compacted endocardial layer with prominent trabeculation and deep recesses that communicate with the LV cavity but not with the coronary circulation, ${ }^{1}$ probably due to an arrest of compaction during intrauterine life. It can be isolated or associated with other congenital diseases. This can lead to chronic heart failure, lifethreatening arrhythmias and systemic embolism. ${ }^{1}$

\section{Learning points}

Left ventricular (LV) hypertrabeculation is defined by the presence of three or more trabeculations apically and to the level of papillary muscles.

- Hypertrabeculation of LV can be a benign finding but can also be associated with left ventricular non-compaction (LVNC), hypertrophic cardiomyopathy, dilated cardiomyopathy and heart failure.

- LVNC is distinguished from hypertrabeculation by the extensive non-compacted endocardial layer with prominent hypertrabeculations and a thin compacted myocardial layer.

Contributors NI wrote the initial draft. HA helped with editing. WA supervised and prepared the images.

Competing interests None declared.

Patient consent Obtained.

Provenance and peer review Not commissioned; externally pee reviewed.

\section{REFERENCES}

1 Peritz DC, Vaughn A, Ciocca M, et al. Hypertrabeculation vs left ventricular noncompaction on echocardiogram: a reason to restrict athletic participation? JAMA Intern Med 2014;174:1379-82.

2 Gati S, Chandra N, Bennett RL, et al. Increased left ventricular trabeculation in highly trained athletes: do we need more stringent criteria for the diagnosis of left ventricular non-compaction in athletes? Heart 2013:99:401-8.

Copyright 2016 BMJ Publishing Group. All rights reserved. For permission to reuse any of this content visit http://group.bmi.com/group/rights-licensing/permissions.

BMJ Case Report Fellows may re-use this article for personal use and teaching without any further permission.

Become a Fellow of BMJ Case Reports today and you can:

- Submit as many cases as you like

- Enjoy fast sympathetic peer review and rapid publication of accepted articles

- Access all the published articles

- Re-use any of the published material for personal use and teaching without further permission

For information on Institutional Fellowships contact consortiasales@bmjgroup.com

Visit casereports.bmj.com for more articles like this and to become a Fellow 